\title{
Functional Evaluation of Prolactin Secretion in Patients with Hypothalamic-Pituitary Disorders
}

\author{
G. Tolis, M. Goldstein, and H. G. Friesen \\ From McGill University Clinic, Division of Endocrinology, Royal Victoria \\ Hospital, Montreal 112, P.Q., Canada
}

A B S T R A C T Prolactin secretion was assessed in 23 patients with hypothalamic-pituitary disorders using L-Dopa suppression, chlorpromazine ( CPZ), and thyrotropin-releasing hormone (TRH) stimulation tests. Based on the responses to these tests, three groups of patients were identified: those with panhypopituitarism (group I) and those with partial hypopituitarism either with (group II) or without (group III) evidence of hypothalamic involvement.

Panhypopituitary patients ( group I) consistently had low serum prolactin values and failed to respond to all tests. Patients with hypothalamic involvement (group II) exhibited ( $a$ ) elevated basal prolactin values, $(b)$ an increase in serum prolactin after $\mathrm{TRH}$ stimulation, (c) blunted response to L-Dopa, and $(d)$ lack of response to chlorpromazine stimulation. Patients with partial hypopituitarism but without hypothalamic involvement (group III) had normal serum prolactin levels and suppressed normally after L-Dopa; although the magnitude of response to both stimulatory agents was significantly lower than normally found the ratio of prolactin levels post-CPZ and TRH ( $\Delta$ prolactin $\mathrm{CPZ} / \Delta$ prolactin $\mathrm{TRH}$ ) was similar to the ratio of normal individuals suggesting that these patients (group III) had a normal hypothalamic-pituitary prolactin axis.

In the 23 patients studied, the most consistent disorder of pituitary function proved to be an abnormal response to one or other of the three tests employed for the evaluation of prolactin secretion. Hence these tests have considerable potential as a sensitive screening procedure in the evaluation of patients suspected of having hypothalamic-pituitary disease.

\section{INTRODUCTION}

Functional tests have been proposed to investigate the hypothalamic-pituitary prolactin axis using thyrotropin-

Reccized for publication 22 Junc 1972 and in revised form 1 Decomber 1972, releasing hormone $(\mathrm{TRH}),{ }^{1}$ chlorpromazine $(\mathrm{CPZ})$, and L-Dopa $(1,2)$. In normal individuals serum prolactin concentration is increased by the first two agents. whereas it is decreased by L-Dopa. Although the precise mechanism of action of each agent has not been clearly delineated in man, animal experiments suggest that $\mathrm{TRH}$ acts directly on the pituitary to stimulate prolactin secretion $(3,4)$, whereas $C P Z$ and L-Dopa act on the hypothalamus (5) presumably decreasing or increasing the secretion of prolactin-inhibiting factor (PIF) respectively $(5,6)$; however, a direct effect of L-Dopa on the pituitary has not been excluded (7).

The application of all three tests in individual patients should allow one to distinguish an absolute deficiency of prolactin-secreting cells from defects in the control of prolactin secretion. A response to $\mathrm{TRH}$ or to $\mathrm{CPZ}$ would indicate the presence of functioning pituitary prolactin cells; on the other hand, a normal response to TRH but not to $\mathrm{CPZ}$ would suggest a hypothalamic disorder. Failure to decrease serum prolactin after L-Dopa would indicate that there is impaired secretion of PIF or that the prolactin cells have escaped from hypothalamic inhibition and are functioning autonomously.

Each of these agents has been used singly to stimulate or inhibit prolactin secretion in normal subjects (8-10) and in patients with hypothalamic-pituitary disorders $(11,12)$ but there has been no systematic analysis of the usefulness of all three agents in the evaluation of patients with hypothalamic-pituitary disorders. 23 of these patients were fully investigated using all three tests. On the basis of the data obtained, it is possible to classify patients with impairment of prolactin secretion into three categories: those with panhypopituitarism (group I) ; those with partial hypopituitarism with hypothalamic involvement (group II); those with partial

${ }^{1}$ Abbreviations used in this paper: $\mathrm{CPZ}$, chlorpromazine; $\mathrm{GH}$, growth hormone; PIF, prolactin-inhibiting factor; PRF, prolactin-releasing hormone; TRH, thyrotropin-releasing hormone. 
hypopituitarism without hypothalamic involvement (group III).

\section{METHODS}

Subjects. A total of 23. patients with clinical and laboratory evidence of abnormal hypothalamic-hypophyseal function were studied (Tables I-III) and divided into three groups.

Group I. Nine patients with panhypopituitarism.

Group II. Seven patients with impaired hypophyseal function with evidence of hypothalamic involvement.

Group III. Seven patients with partial hypopituitarism.

All patients underwent routine examinations including chest $\mathrm{X}$ ray, skull $\mathrm{X}$ ray, ECG (electrocardiogram), EEG (electroencephalogram), brain scan, standard biochemical and hematological tests, and complete opthalmological evaluation. All patients with an abnormal sella turcica had tomography, pneumoencephalography, and carotid angiography.

The hypothalamic-hypophyseal function was evaluated as follows: growth hormone (GH) was measured by radioimmunoassay in serum samples obtained in the fasting state under basal conditions and also 60-90 min after the onset of nocturnal sleep (13); during an arginine infusion and/or an insulin-induced hypoglycemia (14); and after $0.5 \mathrm{~g} \mathrm{~L}-$ Dopa (15-17). A response was considered normal if any $\mathrm{GH}$ value exceeded $5 \mathrm{ng} / \mathrm{ml}$.
The pituitary-thyroid axis was evaluated by determining $\mathrm{T}_{4}$ levels, thyroxine-binding index, $24 \mathrm{~h}{ }^{131} \mathrm{I}$ uptake, and in most of the patients, serum thyroid-stimulating hormone (TSH) before and after TRH administration $(18,19)$. The normal range of serum TSH and $\mathrm{T}_{4}$ under basal conditions in our laboratory is $0-8 \mu \mathrm{U} / 100 \mathrm{ml}$ and $4-11 \mu \mathrm{g} / 100 \mathrm{ml}$, respectively.

Luteinizing hormone $(\mathrm{LH})$ and follicle-stimulating hormone (FSH) were measured in blood and in urine by specific radioimmunoassays $(20,21)$, as well as indirectly by the determination of urinary estriol and plasma testosterone. All measurements were done under basal conditions and in some patients after clomiphene citrate stimulation (50 mg twice daily $\times 7$ days $)(22,23)$. Normal values in our laboratory are $\mathrm{FSH}: 10-30 \mu \mathrm{g} / 100 \mathrm{ml}$ in adults, $>50$ in midcycle or postmenopausally; $\mathrm{LH}: 1-20 \mu \mathrm{g} / 100 \mathrm{ml},>20$ in midcycle or postmenopausally; testosterone: $275-1100 \mathrm{ng} / 100 \mathrm{ml}$; estrogen : $18-100 \mu \mathrm{g} / 24 \mathrm{~h}$. Normal responses to clomiphene are defined as a twofold increase of serum or urinary FSHLH above base-line values.

The pituitary reserve of ACTH was assessed by measuring 17-ketogenic steroids (KGS) during the administration of oral Metopirone (24), ( $0.75 \mathrm{~g}$ at 4-hourly intervals for $24 \mathrm{~h}$ ) and by the determination of plasma cortisol during the induction of hypoglycemia after intravenous insulin.

Serum prolactin was measured by radioimmunoassay (25), while fasting, after L-Dopa suppression test (0.5 g

TABLE I

Clinical and Laboratory Data on Patients with Panhypopituitarism (Group I)

\begin{tabular}{|c|c|c|c|c|c|c|c|c|c|c|c|c|c|c|c|c|c|c|}
\hline \multirow[b]{2}{*}{ Name } & \multirow[b]{2}{*}{ Age } & \multirow[b]{2}{*}{ Sex } & \multirow[b]{2}{*}{ Diagnosis } & \multicolumn{2}{|c|}{ Abnormal } & \multirow[b]{2}{*}{ GH } & \multirow[b]{2}{*}{$\mathrm{E}$} & \multirow{2}{*}{\multicolumn{2}{|c|}{ FSH-LH }} & \multirow[b]{2}{*}{$T$} & \multirow[b]{2}{*}{$17-\mathrm{KGS}$} & \multirow[b]{2}{*}{$\mathbf{F}$} & \multirow[b]{2}{*}{ TSH } & \multirow[b]{2}{*}{$T_{4}$} & \multicolumn{4}{|c|}{ Prolactin, $n g / m l$} \\
\hline & & & & X ray & $\begin{array}{l}\text { Ophthal- } \\
\text { mology }\end{array}$ & & & & & & & & & & $\underset{\bar{x}}{\text { Basal }}$ & $\nabla$ L-dopa & $\triangle \mathrm{CPZ}$ & $\Delta \mathrm{TRH}$ \\
\hline L. B. & 45 & $\mathbf{F}$ & $\begin{array}{l}\text { Surgical hypophy- } \\
\text { sectomy for diabetic } \\
\text { retinopathy }\end{array}$ & + & + & $\begin{array}{l}\text { В } 0.5 \\
\text { P } 0.5\end{array}$ & $<10$ & 3.5 & 0.9 & & $\begin{array}{l}1.5 \\
1.5\end{array}$ & $\begin{array}{l}1.0 \\
1.5\end{array}$ & $\begin{array}{l}0 \\
0\end{array}$ & 1.5 & 1.0 & 0 & 1.5 & 2.0 \\
\hline J. Y. & 35 & $\mathbf{M}$ & $\begin{array}{l}\text { Surgical hypophy- } \\
\text { sectomy for diabetic } \\
\text { retinopathy }\end{array}$ & + & + & $\begin{array}{ll}\text { B } & 0.5 \\
\text { P } & 0.5 \\
\text { B } & 0.8\end{array}$ & & 4.0 & 1.8 & 75 & $\begin{array}{l}2.0 \\
2.5 \\
2.0\end{array}$ & $\begin{array}{l}2.0 \\
\\
2.5 \\
1.8\end{array}$ & $\begin{array}{l}0 \\
0\end{array}$ & 2.0 & 7.0 & 1 & 2.5 & 0 \\
\hline B. $\mathbf{R}$. & 65 & $\mathbf{M}$ & Chromophobe adenoma & + & + & $\begin{array}{ll}\text { P } & 0.8 \\
\text { B } & 0.8\end{array}$ & $<10$ & & 1.6 & 75 & $\begin{array}{l}2.0 \\
1.5\end{array}$ & $\begin{array}{l}3.0 \\
2.0\end{array}$ & $\begin{array}{l}0 \\
0\end{array}$ & 2.2 & 2.0 & 3 & 0 & 2 \\
\hline L. J. & 50 & $\mathbf{F}$ & Sheehan's syndrome & - & - & $\begin{array}{l}\text { P } 2.0 \\
\text { B } 2.0\end{array}$ & & & $\begin{array}{l}1.8 \\
1.3\end{array}$ & 100 & $\begin{array}{l}1.5 \\
1.8\end{array}$ & $\begin{array}{l}2.0 \\
2.5\end{array}$ & $\begin{array}{l}0 \\
0\end{array}$ & 1.5 & 1.0 & 1 & 1.5 & 0 \\
\hline C. $\mathbf{R}$. & 18 & $\mathbf{M}$ & Pituitary tumor & + & + & $\begin{array}{ll}\text { P } & 3.0 \\
\text { B } & 2.5\end{array}$ & & 10. & 3.0 & 84 & $\begin{array}{c}1.8 \\
*\end{array}$ & 2.5 & $\begin{array}{l}0 \\
0\end{array}$ & 3.0 & 4.0 & 1 & 0 & 0 \\
\hline B. J. & 24 & $\mathbf{M}$ & $\begin{array}{l}\text { Idiopathic hypo- } \\
\text { pituitarism }\end{array}$ & - & - & $\begin{array}{ll}P & 4.0 \\
\text { B } & 1.0\end{array}$ & & $\begin{array}{c}10 . \\
4.5\end{array}$ & $\begin{array}{l}3.0 \\
1.5\end{array}$ & 120 & $\begin{array}{c}* \\
1.5\end{array}$ & 2.0 & $\begin{array}{l}0 \\
0\end{array}$ & 1.0 & 1.0 & 2 & 0 & 1 \\
\hline B. L. & 68 & $\mathbf{M}$ & Pituitary apoplexy & + & + & $\begin{array}{ll}\text { P } & 1.0 \\
\text { B } & 0.5\end{array}$ & $<10$ & 4.5 & $\begin{array}{l}2.0 \\
3.0\end{array}$ & & $\begin{array}{l}3.0 \\
*\end{array}$ & 3.0 & $\begin{array}{l}0 \\
0\end{array}$ & 1.0 & 2.0 & 0 & 0 & 0 \\
\hline B. S. & 48 & $\mathbf{F}$ & Pituitary apoplexy & + & + & $\begin{array}{ll}\text { P } & 0.5 \\
\text { B } & 0.5\end{array}$ & $<10$ & 3.0 & 1.6 & & $\begin{array}{c}* \\
3.0\end{array}$ & 2.5 & $\begin{array}{l}\mathbf{0} \\
\mathbf{0}\end{array}$ & 1.8 & 2.0 & 0 & $\mathbf{0}$ & 0 \\
\hline R. L. & 68 & $\mathbf{F}$ & $\begin{array}{l}\text { Cavernous sinus } \\
\text { thrombosis }\end{array}$ & + & + & P 1.5 & & 3.0 & & & 4.5 & 4.0 & 0 & & & 0 & 0 & 0 \\
\hline
\end{tabular}

* On replacement; $\nabla$, decrease below basal; $\Delta$, increase above basal; E, estrogens; T, testosterone; F, cortisol; $\overline{\mathbf{x}}$, mean; B, basal; P, peak; $17-\mathrm{KGS}, 17-\mathrm{ketogenic}$ steroids. 
orally) and during CPZ (25 mg intramuscularly) and TRH ( $400 \mu \mathrm{g}$ intravenously) stimulation tests, as previously described (1). Blood samples during L-Dopa, CPZ, and TRH tests were taken at $-15,0,30,60,120,180 \mathrm{~min},-15,0$, $30,60,90,120 \mathrm{~min}$, and $-15,0,15,30,45,60,90-\mathrm{min}$ intervals, respectively.

Serum prolactin values less than $4 \mathrm{ng} / \mathrm{ml}$ after L-Dopa administration or a twofold increase in serum prolactin after CPZ injection or a mean increase of $20 \mathrm{ng} / \mathrm{ml}$ in males and $40 \mathrm{ng} / \mathrm{ml}$ in females after $\mathrm{TRH}$ stimulation were considered to be normal responses (1).

\section{RESULTS}

Group I. (Table I). The patients in this group showed marked deficiencies of all the anterior pituitary hormones, including prolactin. The mean basal prolactin level (average of five fasting samples) was significantly lower than that of normal subjects (Table IV) and that of patients with hypothalamic disease (group II) or partial hypopituitarism (group III). Only patients with panhypopituitarism repeatedly had values less than 4 $\mathrm{ng} / \mathrm{ml}$. Both direct $(\mathrm{TRH})$ and indirect $(\mathrm{CPZ})$ stimulatory agents failed to increase serum prolactin, indicating a marked deficiency of functioning prolactin cells. In addition, serum TSH did not increase after TRH administration.

Group II. (Table II). Although the group was heterogeneous, it was quite homogeneous in so far as prolactin responses to the three tests were concerned. There are several points worth noting. (a) The mean basal prolactin was higher than in normals $(P<0.005)$ (Table IV) or panhypopituitary patients $(P<0.001)$. (b) The inhibitory response to L-Dopa was blunted. Although the absolute change in serum prolactin was a satisfactory one, percentage wise this response was significantly different than in normals $(P<0.001)$. Serum prolactin showed only a $44 \%$ decrease in contrast to the $80 \%$ decrease of the normal subjects. (c) CPZ administration failed to increase serum prolactin levels. This response was similar to that seen in the panhypopituitary patients, but differed significantly from the normals and from the partial hypopituitary patients without hypothalamic involvement $(P<0.001) .(d)$ The increase in serum prolactin after TRH indicated the presence of functioning prolactin cells and differentiated this group from the panhypopituitary patients $(\mathrm{P}<0.001)$.

Group III. (Table III). The patients in this group showed evidence of partial anterior pituitary deficiency due, in the majority (seven out of eight), to incomplete hypophyseal destruction by pituitary tumors. Mean basal prolactin levels did not differ from normals but were significantly higher $(P<0.001)$ than those of the panhypopituitary group (Table IV) L-Dopa administration effectively decreased serum prolactin levels. However, after CPZ stimulation, serum prolactin did not rise as much as in normal subjects but the increase was significantly greater than that noted in the panhypopitui-

TABLE II

Clinical and Laboratory Data on Patients with Hypothalamic Disease (Group II)

\begin{tabular}{|c|c|c|c|c|c|c|c|c|c|c|c|c|c|c|c|c|c|c|}
\hline \multirow[b]{2}{*}{ Name } & \multirow[b]{2}{*}{ Age } & \multirow[b]{2}{*}{ Sex } & \multirow[b]{2}{*}{ Diagnosis } & \multicolumn{2}{|c|}{ Abnormal } & \multirow[b]{2}{*}{$\mathrm{GH}$} & \multirow[b]{2}{*}{$\mathrm{E}$} & \multirow{2}{*}{\multicolumn{2}{|c|}{ FSH-LH }} & \multirow[b]{2}{*}{$\mathrm{T}$} & \multirow[b]{2}{*}{ 17-KGS } & \multirow[b]{2}{*}{$\mathrm{F}$} & \multirow[b]{2}{*}{ TSH } & \multirow[b]{2}{*}{$T_{4}$} & \multicolumn{4}{|c|}{ Prolactin, $n g / m l$} \\
\hline & & & & $\mathrm{X}$ ray & $\begin{array}{l}\text { Ophthal- } \\
\text { mology }\end{array}$ & & & & & & & & & & $\frac{\text { Basal }}{x}$ & $\nabla$ L-dopa & $\triangle \mathrm{CPZ}$ & $\Delta \mathrm{TRH}$ \\
\hline & & & & & & В 0.5 & & 7.0 & 1.6 & 90 & 2.0 & 1.0 & 0 & 4.0 & 9.0 & & & \\
\hline \multirow[t]{3}{*}{ L. J. } & 25 & $\mathbf{M}$ & Idiopathic panhypo- & - & - & & & & & & & & & & & & & \\
\hline & & & pituitarism & & & P 0.5 & & 9.0 & 2.3 & & 2.5 & 1.0 & 14 & & & 6.0 & 1.0 & 19 \\
\hline & & & & & & B 2.5 & $<10$ & & 3.0 & & 3.0 & 1.5 & 0 & 3.5 & 7.0 & & & \\
\hline \multirow[t]{3}{*}{ R. D. } & 27 & $\mathrm{~F}$ & Craniopharyngioma & +1 & - & & & & & & & & & & & & & \\
\hline & & & & & & P 4.0 & & & & & 4.5 & 3.3 & 27 & & & 5.0 & 1.5 & 10 \\
\hline & & & & & & B 2.0 & 45 & & 8.0 & & 7.0 & 20 & 2 & 8.0 & 22 & & & \\
\hline \multirow[t]{3}{*}{ O. E. } & 16 & $\mathrm{~F}$ & Perinatal trauma & - & - & & & & & & & & & & & & & \\
\hline & & & Mental retardation & & & P 8.0 & & & & & 7.0 & 20 & 18 & & & 4.0 & 1.0 & 15 \\
\hline & & & & & & В 0.5 & & 4.5 & 1.0 & 100 & 1.5 & 1.5 & 0 & 2.0 & 10 & & & \\
\hline \multirow[t]{3}{*}{ O. J. } & 56 & $\mathbf{M}$ & Suprasellar & + & + & & & & & & & & & & & & & \\
\hline & & & chromophobe adenoma & & & P 5.0 & & & & & 2.2 & 1.5 & 0 & & & 5.0 & 1.0 & 7 \\
\hline & & & & & & B 1.5 & & & 1.5 & 120 & 5.0 & 6.0 & 0 & 1.8 & 10 & & & \\
\hline \multirow[t]{3}{*}{ C. C. } & 43 & $\mathbf{M}$ & Suprasellar & + & + & & & & & & & & & & & & & \\
\hline & & & chromophobe adenoma & & & P 6.8 & & & & & 16.0 & 12.0 & $\mathbf{0}$ & & & 5.0 & 1.5 & 9 \\
\hline & & & & & & В 0.5 & $<10$ & & 2.6 & & 6.5 & 5.0 & 0 & 6.0 & 27 & & & \\
\hline \multirow[t]{3}{*}{ C. $\mathbf{K}$. } & 50 & $\mathbf{F}$ & Suprasellar & + & + & & & & & & & & & & & & & \\
\hline & & & chromophobe adenoma & & & $\mathrm{P} 0.5$ & & & & & 18.0 & 13.0 & 0 & & & 6.0 & 2.0 & 7 \\
\hline & & & & & & В 2.5 & & & 1.4 & 90 & 5.0 & 7.0 & 1.0 & 6.5 & 25 & & & \\
\hline \multirow[t]{2}{*}{ A. E. } & 64 & $\mathbf{M}$ & Olfactory neuroblastoma & + & + & & & & & & & & & & & & & \\
\hline & & & & & & P 7.7 & & & & & 5.0 & 7.0 & 9.0 & & & 6.0 & 1.0 & 8 \\
\hline
\end{tabular}

* For explanation of abbreviations see Table I. 
TABLE III

Clinical and Laboratory Data on Patients with Partial Hypopituitarism (Group III)

\begin{tabular}{|c|c|c|c|c|c|c|c|c|c|c|c|c|c|c|c|c|c|c|}
\hline \multirow[b]{2}{*}{ Name } & \multirow[b]{2}{*}{ Age } & \multirow[b]{2}{*}{ Sex } & \multirow[b]{2}{*}{ Diagnosis } & \multicolumn{2}{|c|}{ Abnormal } & \multirow[b]{2}{*}{$\mathrm{GH}$} & \multirow[b]{2}{*}{$\mathrm{E}$} & \multirow{2}{*}{\multicolumn{2}{|c|}{ FSH-LH }} & \multirow[b]{2}{*}{$\mathrm{T}$} & \multirow[b]{2}{*}{ 17-KGS } & \multirow[b]{2}{*}{$\mathrm{F}$} & \multirow[b]{2}{*}{$\mathrm{TSH}$} & \multirow[b]{2}{*}{$T_{4}$} & \multicolumn{4}{|c|}{ Prolactin, $n g / m i$} \\
\hline & & & & $\mathrm{X}$ ray & $\begin{array}{l}\text { Ophthal- } \\
\text { mology* }\end{array}$ & & & & & & & & & & $\underset{\bar{x}}{\text { Basal }}$ & $\nabla$ L-dopa & $\Delta \mathrm{CPZ}$ & $\Delta \mathrm{TRH}$ \\
\hline D. A. & 4.3 & $\mathbf{M}$ & Pituitary :umor & + & + & B 1.0 & & 5.0 & 1.5 & 165 & 4.5 & 1.0 & 0 & 1.5 & 10.0 & & & \\
\hline & & & & & & P 1.5 & & & 1.5 & & 14.0 & 3.0 & 0 & & & 9.0 & 7.0 & 7.0 \\
\hline S. G & 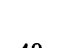 & M & & & & B 1.5 & & 6.0 & 2.0 & 125 & 8.5 & & 0 & 8.0 & 12.0 & & & \\
\hline S.G. & 40 & $\mathrm{M}$ & Pituitary tumor & + & - & P 5.7 & & & 2.0 & & 49 & & 10 & & & 8.0 & 7.0 & 8.0 \\
\hline H. F. & 66 & $\mathbf{M}$ & Pituitary tumor & + & + & B 1.0 & & 200 & 2.5 & 75 & 1.5 & 1.0 & 0 & 1.5 & 8.5 & & & \\
\hline & & & & & & $\begin{array}{ll}\text { P } 1.0 \\
\end{array}$ & & & & & 3.0 & 1.0 & 0 & & & 6.0 & 5.0 & 8.0 \\
\hline & & & & & & P 1.0 & & & 1.0 & & 22.0 & 16.0 & 2.0 & & & 6.0 & 5.0 & 7.0 \\
\hline B. D. & 19 & $\mathbf{M}$ & Idiopathic GH deficiency & - & _- & B 0.5 & & 4.0 & 2.0 & 90 & 7.9 & 6.0 & 0 & 8.0 & 7.0 & & & \\
\hline & & & & & & $\begin{array}{ll}\text { P } & 2.6 \\
\text { B } & 1.0\end{array}$ & & 10.0 & $\begin{array}{l}9.8 \\
6.6\end{array}$ & $\begin{array}{l}185 \\
189\end{array}$ & $\begin{array}{r}19.0 \\
7.0\end{array}$ & $\begin{array}{r}18.0 \\
9.0\end{array}$ & $\begin{array}{l}7.0 \\
0\end{array}$ & 7.5 & 12.0 & 6.0 & 8.0 & 8.0 \\
\hline G. N. & 60 & $\mathbf{M}$ & Meningioma & + & + & P 1.0 & & & & & & 27.0 & 9.0 & 6 & & 7.0 & 6.0 & 9.0 \\
\hline L. I. & 66 & $\mathbf{M}$ & Pituitary tumor & + & + & $\begin{array}{ll}\text { В } 1.5 \\
\text { P } 1.5\end{array}$ & & & 1.0 & & 6.5 & $\begin{array}{r}7.0 \\
17.0\end{array}$ & & 6.5 & 5.0 & 5.0 & 6.0 & 8.0 \\
\hline
\end{tabular}

* For explanation of abbreviations see Table I.

tary group or the patients with hypothalamic disorders. After TRH administration, serum prolactin concentrations were significantly higher than seen in the panhypopituitary patients but lower than that of the normal subjects or of the patients with hypothalamic involvement.

In the three groups of patients studied the most frequent abnormality of pituitary function was some impairment of prolactin secretion. The next most common deficiency observed was that of gonadotropin secretion

TABLE IV

The Mean Serum Prolactin Concentrations Under Basal Conditions and the Change after Provocative Tests*

\begin{tabular}{|c|c|c|c|c|}
\hline & Basal & $\nabla$ L-dopa & $\triangle \mathrm{CPZ}$ & $\triangle T$ TRH \\
\hline Normal & & & & \\
\hline $\begin{array}{l}\text { Males } \\
\text { Females }\end{array}$ & $7 \pm 3$ & $6 \pm 3$ & $\begin{array}{l}20 \pm 9 \\
30 \pm 10\end{array}$ & $\begin{array}{l}18 \pm 4 \\
36 \pm 8\end{array}$ \\
\hline Hypopituitary patients & & & & \\
\hline $\begin{array}{c}\text { I Panhypopituitary } \\
\text { II With hypothalamic } \\
\text { involvement } \\
\text { III Without hypothalamic } \\
\text { involvement }\end{array}$ & $\begin{array}{l}2 \pm 2 \ddagger \\
16 \pm 88 \\
9 \pm 2\end{array}$ & $\begin{array}{l}1 \pm 1 \ddagger \\
5 \pm 1 \\
7 \pm 1\end{array}$ & $\begin{array}{l}1 \pm 1 \ddagger \\
1 \pm 1 \ddagger \\
6 \pm 18\end{array}$ & $\begin{array}{r}1 \pm 1 \ddagger \\
11 \pm 4 \| \\
8 \pm 18\end{array}$ \\
\hline
\end{tabular}

* Values are compared between the hypopituitary patients and the normal males. Concentrations are expressed in nanograms per milliliter.

$\ddagger P<0.001$.

$\& P<0.005$.

$\| P<0.025$. followed by deficiencies of GH, ACTH, and TSH (Table V). Group I, as expected, was characterized by a deficiency of secretion of all pituitary hormones studied, whereas in group II, besides prolactin, deficiency of gonadotropin $(86 \%)$ and ACTH $(70 \%)$ secretion occurred frequently; in patients in group III, the most frequently observed deficiency, next to prolactin, was that of GH secretion $(86 \%)$.

\section{DISCUSSION}

The prolactin cells of the pituitary and the hypothalamic mechanisms controlling prolactin secretion constitute the hypothalamic pituitary prolactin (h-p-p) axis. Therefore the complete investigation of the axis requires the evaluation of both the pituitary cells and their hypothalamic control mechanisms.

\begin{tabular}{ccccccc} 
TABLE V \\
\multicolumn{8}{c}{$\begin{array}{c}\text { Distribution of Pituitary Hormone Deficiencies in } \\
\text { Patients with Hypothalamic-Pituitary Disorders }\end{array}$} \\
\hline Group & no. & Prolactin & Gonadotrophins & GH & ACTH & TSH \\
\hline I & 9 & 9 & 9 & 9 & 9 & 9 \\
II & 7 & 7 & 6 & 3 & 5 & 2 \\
III & 7 & 7 & 4 & 6 & 1 & 3 \\
Total & 23 & 23 & 19 & 18 & 15 & 14 \\
\hline
\end{tabular}


Because TRH has a direct action on pituitary prolactin cells, the magnitude of the increase in serum prolactin values reflects the pituitary prolactin reserve. Failure to respond to TRH indicates an absolute prolactin deficiency, as observed in the panhypopituitary patients (group I). In all but one of these patients, serum prolactin was consistently less than $4 \mathrm{ng} / \mathrm{ml}$, even after TRH stimulation. In one patient (B. R., Table I). the basal serum prolactin was normal, emphasizing the necessity of stimulatory tests to avoid diagnostic errors.

Prolactin secretion is regulated by the hypothalamus and mediated via two factors: an inhibitory one (prolactin-inhibiting factor, PIF) $(26,27)$ which decreases prolactin secretion and a stimulatory one (prolactinreleasing factor, PRF) (28-30) which increases it. Although little is known about the control of PRF, PIF secretion appears to be under dopaminergic control (3133 ) and so agents which increase dopamine (e.g. L-Dopa) should increase PIF secretion thereby decreasing prolactin secretion. Experimentally and clinically this occurs after the administration of L-Dopa $(1,6,11)$. Conversely, when PIF secretion is suppressed by agents such as $\mathrm{CPZ}$ then prolactin secretion should increase. Again, this is supported by experimental and clinical observations $(1,2,11,34)$. In patients with hypothalamic involvement, group II, the observed responses are predictable from the theoretical considerations of the physiologic and pharmacologic factors which are known to regulate prolactin secretion. The most significant feature in this group of patients is that despite the absence of any increase in serum prolactin after $\mathrm{CPZ}$, an increase occurred after TRH. Therefore it is obvious that a diagnosis of isolated prolactin deficiency (35) cannot be entertained unless both stimulatory agents fail to increase serum prolactin concentrations.

Patients without hypothalamic disease (group III) had normal basal serum prolactin concentrations and suppressed normally with L-Dopa. In these patients the rise in serum prolactin after TRH and $\mathrm{CPZ}$ was lower than normally found, suggesting the existence of a decreased pituitary prolactin reserve. However, the increase in prolactin after $\mathrm{CPZ}$ and TRH was similar. Hence the ratio of the responses $\Delta$ prolactin post-CPZ/ $\Delta$ prolactin post-TRH was the same as the ratio found in normal individuals (Fig. 1). This finding is the hallmark of the group III patients and it differentiates them from patients with hypothalamic involvement (group II).

One of the most fascinating findings was that in all patients studied with the three tests, an impairment of prolactin secretion was detected in each patient whereas no other clinical or laboratory test of pituitary function proved to be so consistently abnormal (Table V). Therefore we suggest that in all patients in whom a hypothala-

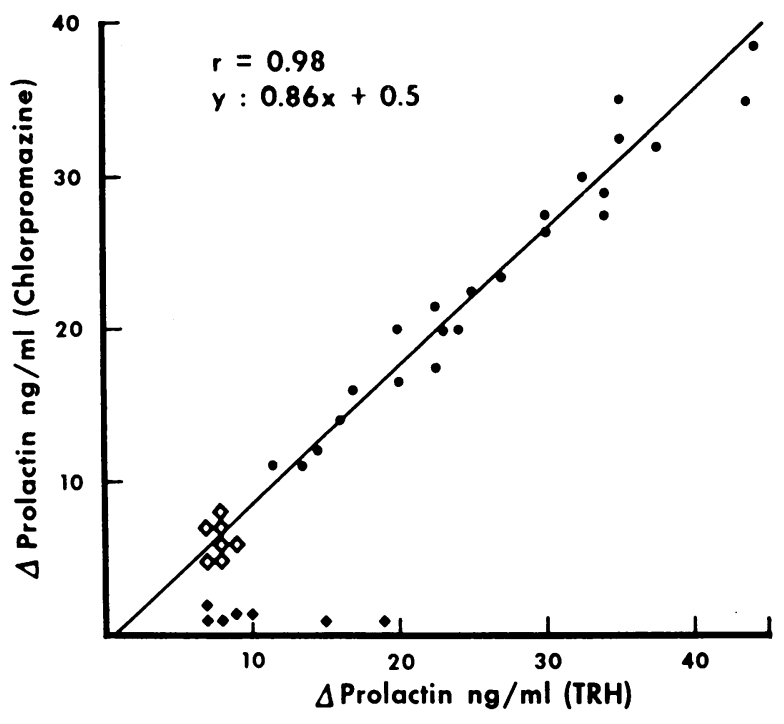

FIGURE 1 The increase in serum prolactin concentration after TRH and after $\mathrm{CPZ}$ is plotted on the abscissa and ordinate respectively in normal subjects $(\bullet)$ and patients with partial hypopituitarism either with (group II, $\bullet$ ) or without (group III, $\diamond$ ) hypothalamic disease. The regression line was determined by the method of least squares and the portion of the line below the normal values ( $\bullet$ ) was extrapolated to the intercept.

mic or pituitary disorder is suspected the complete functional evaluation of prolactin secretion is indicated.

\section{ACKNOWLEDGMENTS}

We wish to acknowledge the technical assistance of Miss Suzanne Peeters and the secretarial help of Mrs. Jane Coppenrath and Miss Jackie Fee.

This study was supported by grants MRC-MA 1862 and U. S. Public Health Service HD 01727-07 (Dr. Friesen).

\section{REFERENCES}

1. Friesen, H., H. Guyda, P. Hwang, J. E. Tyson, and A. Barbeau. 1971. Functional evaluation of prolactin secretion: a guide to therapy. J. Clin. Invest. 51: 706.

2. Friesen, H., P. Hwang, H. Guyda, G. Tolis, J. Tyson, and R. Myers. 1972. A radioimmunoassay for human prolactin; physiological, pathological and pharmacological factors which affect the secretion of prolactin. The 4th Tenovus Workshop on Prolactin and Carcinogenesis, Cardiff, Wales. K. Griffiths and A. Boyne, editors. 64.

3. LaBella, F. S., and S. B. Vivian. 1971. Effect of synthetic TRF on hormone release from bovine anterior pituitary in vitro. Endocrinology. 88: 787.

4. Tashjian, F. H., N. J. Barowsky, and D. K. Jensen. 1971. Thyrotropin releasing hormone: direct evidence for stimulation of prolactin production by pituitary cells in culture. Biochem. Biophys. Res. Commun. 43: 516.

5. De Wied, D. 1967. Chlorpromazine and endocrine function. Pharmacol. Rev. 19 : 251.

6. Kamberi, I. A., R. S. Mical, and J. C. Porter. 1971. Effect of anterior pituitary perfusion and intraven-

Evaluation of Human Prolactin Secretion 
tricular injection of catecholamines on prolactin release. Endocrinology. 88: 1012.

7. Birge, C. A., L. S. Jacobs, C. T. Hammer, and W. H. Daughaday. 1970. Catecholamine inhibition of prolactin secretion by isolated rat adenohypophyses. Endocrinology. $86: 120$.

8. Bowers, C. Y., H. G. Friesen, P. Hwang, H. J. Guyda, and K. Folkers. 1971. Prolactin and thyrotropin release in man by synthetic pyroglutamyl histidyl-prolinamide. Biochem. Biophys. Res. Commun. 45: 1033.

9. Jacobs, L. S., P. J. Snyder, J. F. Wilber, R. D. Utiger, and W. H. Daughaday. 1971. Increased serum prolactin after administration of synthetic thyrotropin hormone (TRH) in man. J. Clin. Endocrinol. Metab. 33: 996.

10. L'Hermite, M., L. Vanhaelst, G. Copinschi, R. Leclerq, J. Goldstein, O. D. Bruno, and C. Robyn. 1972. Prolactin release after injection of thyrotropin-releasing hormone in man. Lancet. 1: 763.

11. Kleinberg, D. L., G. L. Noel, and A. G. Frantz. 1971. Chlorpromazine stimulation and L-Dopa suppression of plasma prolactin in man. J. Clin. Endocrinol. Metab. 33: 873.

12. Foley, T. P., Jr., L. S. Jacobs, W. Hoffman, W. H. Daughaday, and R. M. Blizzard. 1972. Human prolactin and thyrotropin concentrations in the serum of normal and hypopituitary children before and after the administration of synthetic thyrotropin-releasing hormone. J. Clin. Invest. $51: 2143$.

13. Daughaday, W. H. 1969. Growth hormone assay in acromegaly gigantism, dwarfism and hypopituitarism. Postgrad. Med. 46: 84.

14. Glick, S. M. 1970. Hypoglycemic threshold for human growth hormone release. J. Clin. Endocrinol. Metab. 30: 619 .

15. Boyd, A. E., III, H. E. Lebovitz, and J. M. Feldman. 1971. Endocrine function and glucose metabolism in patients with Parkinson's disease and other alteration by L-Dopa. J. Clin. Endocrinol. Metab. 33: 829.

16. Eddy, R. L., A. L. Jones, Z. H. Chakmakjian, and M. C. Silverthorne. 1971. Effect of Levodopa on human hypophyseal trophic hormone release. J. Clin. Endocrinol Metab. 33: 709.

17. Kansal, P. C., J. Buse, O. R. Talbert, and M. G. Buse. 1972. The effect of L-Dopa on plasma growth hormone, insulin and thyroxine. J. Clin. Endocrinol. Metab. 34: 99.

18. Karlberg, B., S. Almqvist, and S. Werner. 1971. Effects of synthetic pyroglutamyl-histidyl-proline-amide on serum levels of thyrotropin, cortisol growth hormone, insulin and PBI in normal subjects and patients with pituitary and thyroid disorders. Acta Endocrinol. (Copenhagen). $67: 288$.

19. Costom, B. H., M. M. Grumbach, and S. L. Kaplan. 1971. Effect of thyrotropin-releasing factor on serum thyroid-stimulating hormone. An approach to distinguishing hypothalamic from pituitary forms of idiopathic hypopituitary dwarfism. J. Clin. Invest. 50: 2219.

20. Penny, R., H. J. Guyda, A. Baghdassarian, A. J. Johnson, and R. M. Blizzard. 1970. Correlation of serum follicular stimulating hormone (FSH) and luteinizing hormone ( $\mathrm{LH})$ as measured by radioimmunoassay in disorders of sexual development. J. Clin. Invest. 49: 1847.

21. Baghdassarian, A., H. Guyda, A. J. Johanson, C. J. Migeon, and R. M. Blizzard. 1970. Urinary excretion of radioimmunoassayable luteinizing hormone $(\mathrm{LH})$ in normal male children and adults, according to age and stage of sexual development. J. Clin. Endocrinol. Metab. 31 : 428.

22. Santen, R. J., J. M. Leonard, R. J. Sherins, H. M. Gandy, and C. A. Paulsen. 1971. Short and long term effects of clomiphene citrate on the pituitary-testicular axis. J. Clin. Endocrinol. Metab. 33: 970.

23. Kulin, H. E., M. M. Grumbach, and S. L. Kaplan. 1969. Changing sensitivity of the pubertal gonadal hypothalamic feedback. Science (Wash. D. C.). 166: 1012.

24. Liddle, G. W., H. L. Estep, J. W. Kendall, Jr., W. C. Williams, Jr., and A. W. Townes. 1959. Clinical application of a new test of pituitary reserve. J. Clin. Endocrinol. Metab. 19: 875 .

25. Hwang, P., H. Guyda, and H. Friesen. 1971. A radioimmunoassay for human prolactin. Proc. Natl. Acad. Sci. U.S. A. 68: 1902.

26. Everett, J. W. 1954. Luteotrophic function of autografts of the rat hypophysis. Endocrinology. 54: 685.

27. Meites, J., and C. S. Nicoll. 1969. Adenohypophysis : prolactin. Annu. Rev. Physiol. 28: 57.

28. Nicoll, C. S., R. P. Fiorindo, C. T. McKennee, and J. A. Parsons. 1970. Assay of hypothalamic factors which regulate prolactin secretion. In Hypophysiotropic Hormones of the Hypothalamus: Assay and Chemistry. J. Meites, editor. The Williams \& Wilkins Company. 115.

29. Krulich, L., M. Quijada, and P. Illner. 1971. Localization of prolactin inhibiting factor (PIF), P-releasing factor (PRF), growth hormone-RF (GRF) and GIF activities in the hypothalamus of the rat. Proceedings of the 53rd Meeting of the Endocrine Society. 83.

30. Valverde-R., C., V. Chieffo, and S. Reichlin. 1972. Prolactin-releasing factor in porcine and rat hypothalamic tissue. Endocrinology. 91 : 982.

31. Fuxe, K., and T. Hokfelt. 1966. Further evidence for the existence of tubero-infudibular dopamine neurons. Acta Physiol. Scand. 66: 245.

32. Everett, G. M., and J. R. Borcherding. 1970. L-Dopa : effect on concentrations of dopamine, norepinephrine and serotonin in brains of mice: Science (Wash. D. C.). $168: 849$.

33. Donoso, A. O., W. Bishop, C. P. Fawcett, L. Krulich, and S. M. McCann. 1971. Effects of drugs that modify brain monoamine concentration on plasma gonadotrophin and prolactin level in the rat. Endocrinology. 89: 774.

34. Michinsky, J., Z. K. Lajtos, and F. G. Sulman. 1966. Initiation of lactation by hypothalamic implantation of perphenazine. Endocrinology. 78: 919.

35. Turkington, R. W. 1972. Phenothiazine stimulation test for prolactin reserve. The syndrome of isolated prolactin deficiency. J. Clin. Endocrinol. Metab. 34: 247. 